\title{
The YXXФ motif within the severe acute respiratory syndrome coronavirus (SARS-CoV) 3a protein is crucial for its intracellular transport
}

\author{
Rinki Minakshi ${ }^{1}$ and Kartika Padhan ${ }^{1,2^{*}}$
}

\begin{abstract}
Background: The SARS coronavirus (SARS-CoV) 3a protein functions as an ion channel, induces apoptosis and is important for viral pathogenesis. It is expressed on the cell surface and contains a tyrosine-based sorting motif and a di-acidic motif, which may be crucial for its intracellular trafficking. However the role of these motifs is not fully understood in the case of 3a protein.

Methods: The subcellular distribution of the 3a protein was studied by immunofluorescence staining of cells transfected with wild type and mutant constructs along with markers for different intracellular compartments. Semi-quantitative RT-PCR was performed to estimate the mRNA where as western blotting was carried out to detect protein levels of wild type and mutant 3a proteins. In vitro transcription- translation was performed to estimate cell free protein synthesis.

Results: While the wild type 3a protein is efficiently transported to the plasma membrane, the protein with mutations in the tyrosine and valine residues within the YXXV motif ( $\triangle Y X X \Phi)$ accumulated in the Golgi compartment. However the 3a protein with mutations within the EXD di-acidic motif ( $\triangle$ EXD) showed an intracellular distribution similar to the wild type protein. Increased retention of the $\triangle Y X X \Phi$ protein in the Golgi compartment also increased its association with lipid droplets. The $\triangle Y X X \Phi$ protein also expressed at significantly lower levels compared to the wild type 3a protein, which was reversed with Brefeldin A and Aprotinin.
\end{abstract}

Conclusions: The data suggest that the YXXФ motif of the SARS-CoV 3a protein is necessary for Golgi to plasma membrane transport, in the absence of which the protein is targeted to lysosomal degradation compartment via lipid droplets.

\section{Introduction}

Severe Acute Respiratory Syndrome (SARS) originated in China towards the end of 2002 and quickly spread to about 30 countries by 2003 causing over 800 deaths worldwide [1-4]. The etiological agent of the disease, the SARS Coronavirus (SARS-CoV) was identified and classified as a unique member of beta Coronavirus. The SARS-CoV carries a $\sim 30 \mathrm{~kb}$ positive-sense RNA genome that contains 8 unique open reading frames (ORFs) in addition to the common coronaviral genes $[5,6]$. The Orf3A is the largest among these ORFs and encodes a

\footnotetext{
* Correspondence: kartikpadhan@gmail.com

'International Centre for Genetic Engineering and Biotechnology, New Delhi, India

${ }^{2}$ Laboratory of Systems Biology, National Institute of Allergy and Infectious Diseases, National Institutes of Health, Bethesda, MD 20892, USA
}

protein of 274 amino acids, the deletion of which reduces SARS-CoV replication in cell cultures and murine models of infection [7]. Antibodies against the 3a protein were also found in the sera of SARS patients [8]. Following infection of Vero $\mathrm{E} 6$ or $\mathrm{CaCo} 2$ cells, the 3a protein was found to be associated with virus particles $[9,10]$ and localized to the plasma membrane and perinuclear regions of infected cells [11]. Several studies including ours have shown the 3 a protein to induce apoptosis in host cell [12-14], which is also linked to its ability to form ion channels [15]. The 3a protein also promotes osteoclastogenesis by increasing NF-kB activity [16], and we have shown it to cause ER stress and induce downregulation of the type 1 interferon receptor [14,17].

The $3 \mathrm{a}$ protein contains three transmembrane domains at the $\mathrm{N}$-terminus and a $\mathrm{C}$-terminal cytoplasmic 
domain of $\sim 150$ amino acids [18]. The cytoplasmic domain contains a tyrosine based sorting motif, YXXФ (where $\mathrm{X}$ can be any residue and $\Phi$ is a residue with a bulky hydrophobic side chain) and a di-acidic EXD motif. It has been hypothesized that these motifs assist the $3 \mathrm{a}$ protein in regulating internalization of the viral Spike (S) protein from cell surface to intracellular sites [19]. In a study by Tan et al., the 3a protein lacking both of these motifs failed to express on the cell surface [11]. It has also been reported that the 3a protein is released in membranous structure from cell and mutation in the YXXФ or EXD motif does not impact the release [20]. Tyrosine based sorting motifs are responsible for AP-2 mediated internalization from the cell surface by interacting with $\mu 2$ subunit of the clathrin complex [21]. However the YXXФ motif can also mediate interaction with other members of the clathrin complex including AP-1, AP-3 and AP-4 for transport to different destinations inside the cell [22]. For example, the YXXФ motif has been shown to be required for lysosomal targeting of some proteins like the CD3 chain of the T-cell receptor [23]. The di-acidic motif functions as a canonical ER export signal by mediating interaction with COPII vesicles [24-27] and has been shown to mediate efficient transport of the KAT1 ion channel protein to the plasma membrane [28]. However the functions of these individual motifs within the $3 \mathrm{a}$ protein have not been understood properly.

We previously reported the 3 a protein to localize to the plasma membrane and to interact with Caveolin-1 [29], a protein that is part of lipid-rich regions of the membrane (caveolae) and has several functions in the cells, including the formation of lipid droplets and modulation of lipolysis [30-32]. Lipid droplets are intracellular storage organelles consisting of a core of neutral lipids surrounded by a monolayer of phospholipids [33]. Many proteins have been identified on lipid droplets that are also involved in vesicular transport, membrane fusion and cytoskeletal mobility. Among these are Perilipin A, Caveolins, Phospholipase D, and members of the Rab and ARF families of small GTPases [34-38]. Among viral proteins, the core proteins of hepatitis $C$ virus (HCV) and $G B$ virus $B(G B V-B)$ are known to be associated with lipid droplets [39]. Recent views of lipid droplets emphasize that these might also act as storage vesicles for excess and unfolded proteins [34,40].

In this report we show that the tyrosine based sorting motif (YXXФ) of the 3a protein is responsible for its sorting from the Golgi to plasma membrane. Whereas the wild type 3a protein traffics to plasma membrane efficiently, most of the YXXФ mutants are retained in Golgi and lipid droplets. We also show that increased targeting of the 3 a protein to lipid droplets is associated with its lysosomal degradation. These findings define the role of the YXXФ motif in intracellular and surface transport of the SARS-CoV 3a protein.

\section{Results}

The YXXФ motif of the 3a protein is required for its trafficking to the plasma membrane

Several motifs are present within the amino acid sequence of Orf3a that may be crucial for its intracellular localization. The 274 amino acids (aa) long 3a protein contains three potential transmembrane regions between residues 34-56, 77-99 and 103-125, followed by a cytoplasmic domain of $\sim 150$ aa (Figure 1). The cytoplasmic domain of 3a also contains a tyrosine-based sorting motif, YXXФ (aa 160-163) and a di-acidic motif, EXD (aa 171-173). We compared the amino acid sequences of SARS-CoV 3a protein from several human and bat isolates available in NCBI database (Table 1). YXXФ motif is conserved in all the isolates studied where as the EXD motif is mutated in all the seven bat isolates and one out of 21 human isolates. The EXD motif was proposed to be an endoplasmic reticulum (ER) export signal whereas the YXXФ motif was shown to be crucial for endocytosis from the cell surface [19]. The topology of the 3a protein is such that the $\mathrm{N}$-terminus is exposed to the outside of plasma membrane [11]. To study its cell surface distribution, we made expression constructs for the $3 a$ protein and its mutants with a $\mathrm{N}$-terminal Myc-tag. The 3a protein was expressed in four different cell lines - COS-7, HT29, MDCK and Huh7 and showed intracellular as well as surface localization in all cell types (Figure 2A). This result is consistent with previous reports showing the membrane distribution of the 3a protein [11].

To study the subcellular distribution of the 3 a protein we performed immunofluorescence staining of cells transfected

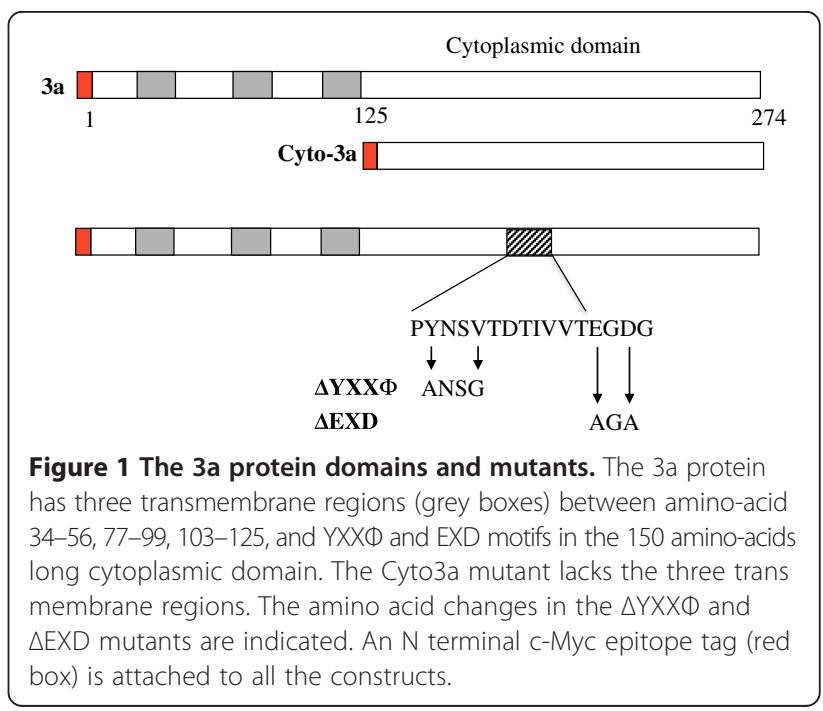


Table 1 Comparison of amino acid sequences in the cytoplasmic tail of different SARS-CoV isolates from human and bat

\begin{tabular}{ll}
\hline Isolates & $\begin{array}{l}\text { Amino acid sequences }(141-180) \\
\text { in the cytoplasmic tail of } 3 \mathrm{a}^{\mathrm{a}}\end{array}$ \\
\hline Human Isolates &
\end{tabular}

Human Isolates

ZJ0301 YDANFVCWHTHNYDYCIPYNSVTDTIWTEGDGISTPKL

URBANI YDANFVCWHTHNYDYCIPYNSVTDTIWTEGDGISTPKL

TWJ YDANFVCWHTHNYDYCIPYNSVTDTIWTEGDGISTPKL

TWI YDANFVCWHTHNYDYCIPYNSVTDTIVTEGDGISTPKL

TOR2 YDANFVCWHTHNYDYCIPYNSVTDTIWTEGDGISTPKL

Sino 3-11 YDANFVCWHTHNYDYCIPYNSVTDTIVTEGDGISTPKL

Sino 1-11 YDANFVCWHTHNYDYCIPYNSVTDTIWTEGDGISTPKL

SIN2774 YDANFVCWHTHNYDYCIPYNSVTDTIVTEGDGISTPKL

SIN2748 YDANFVCWHTHNYDYCIPYNSVTDTIWTEGDGISTPKL

SIN2679

SIN2677

YDANFVCWHTHNYDYCIPYNSVTDTIWTEGDGISTPKL

SIN2500

YDANFVCWHTHNYDYCIPYNSVTDTIWTEGDGISTPKL

LLJ-2004

YDANFVCWHTHNYDYCIPYNSVTDTIWTEGDGISTPKL

HKU39849

GD01

CUHKU-W1

YDANFVCWHTHNYDYCIPYNSVTDTIWTEGDGISTPKL

YDANFVCWHTHNYDYCIPYNSVTDTIWTEGDGISTPKL

YDANFVCWHTHNYDYCIPYNSVTDTIWTAGDGISTPKL

CFB/SZ/94/03

YDANFVCWHTHNYDYCIPYNSVTDTIWTEGDGISTPKL

BJ04

BJ03

YDANFVCWHTHNYDYCIPYNSVTDTIWTEGDGISTPKL

BJ02

YDANFVCWHTHNYDYCIPYNSVTDTIWTEGDGISTPKL

YDANFVCWHTHNYDYCIPYNSVTDTIWTEGDGISTPKL

YDANFVCWHTHNYDYCIPYNSVTDTIWTEGDGISTPKL

BJ01

YDANFVCWHTHNYDYCIPYNSVTDTIWTEGDGISTPKL

Bat Isolates:

W1V1

YDANFVCWHTHNYDYCIPYNSVTDTIVTAGGGISTPKL

RsSHC014

YDANFVCWHTHNYDYCIPYNSVTDTIWTAGDGISTPKL

Rs3367

Rs672

Rf1

YDANFVCWHTHNYDYCIPYNSVTDTIWTAGDGISTPKL

YDANFVCWHTHNYDYCIPYNSVTDTIWTAGDGISTPKL

YDANFVCWHTHNYDYCIPYNSVTDTIWTSGDGISTPKL

HKU3-12

YDANFVCWHTHNYDYCIPYNSVTDTIWTSGDGISTPKL

279/2005

YDANFVCWHTHNYDYCIP YNS I TDTIWTSGDGISTPKL

${ }^{\mathrm{a} A m i n o}$ acid sequences were obtained from National Center for Biotechnology Information (NCBI). The YXXФ (where $X$ is any amino acid and $\Phi$ is an amino acid with a bulky hydrophobic side chain) and EXD motifs are shown in italics whereas mutated motifs are highlighted in bold letters.

with wild type and mutant constructs. The cell surface distribution was observed in non-permeabilized cells with the antibodies against the N-terminal Myc-tag. Staining of permeabilized cells with antibodies against the cytoplasmic region (aa 126-274) of the 3a protein was used to see its total expression and intracellular distribution. The wild type 3a protein was found to localize to the plasma membrane as well as to intracellular regions that appeared to be perinuclear and showed a punctate distribution (Figure 2B).
The Cyto3a protein that lacks the transmembrane domains showed similar intracellular distribution, but was expectedly not found on the plasma membrane (Figure 2B). Surprisingly, the $\triangle \mathrm{YXX} \Phi$ protein with mutations in the tyrosine-based sorting motif was mainly localized in the perinuclear compartment (Figure 2B). On the other hand, the $\triangle \mathrm{EXD}$ protein with the mutations in the diacidic motif distributed similar to the wild type protein. Since an N-terminal myc tag was present on all the proteins and was likely to be exposed extracellularly, staining non-permeabilized cells with the anti-myc antibodies confirmed the plasma membrane localization and proper topology of the $3 \mathrm{a}$ proteins. Only the wild type and $\triangle$ EXD proteins stained with anti-myc antibodies in non-permeabilized cells. These results showed that the 3a proteins are expressed with the correct topology of extracellular $\mathrm{N}$-terminus and cytoplasmic $\mathrm{C}$-terminus. The $\triangle Y X X \Phi$ mutant protein saturated in the intracellular compartment, but was not found at the plasma membrane, showing this tyrosine-based sorting motif to be important for its trafficking to the cell surface. The di-acidic motif, which is a canonical ER export signal, did not show any role in the intracellular trafficking of the 3a protein.

\section{The YXXФ motif in 3a protein is responsible for its Golgi} to plasma membrane sorting

The subcellular distribution of the $\triangle Y X X \Phi$ protein was very different from that of the wild type $3 a$ protein. To further characterize the compartments to which the mutant 3a proteins localize, we expressed them in Huh7 cells together with markers for the ER and Golgi compartments. The wild type and $\triangle \mathrm{EXD}$ proteins were distributed to the cell surface and punctate structures that are likely to represent trafficking vesicles; these also showed minor colocalization with the Golgi compartment (Figure 3A). However, the $\triangle \mathrm{YXX} \Phi$ mutant protein was localized exclusively to the Golgi compartment (Figure 3A). Two subcellular distribution patterns were observed for the proteins. While the first consisted of a predominantly dispersed cytoplasmic and plasma membrane localization with a minor fraction of the protein in the Golgi compartment, the other showed a Golgi-saturated pattern. These distribution patterns for the proteins were quantified in multiple cells using the Golgi marker. An overwhelming majority of cells expressing wild type $3 \mathrm{a}$ or its $\triangle \mathrm{EXD}$ mutant showed the first pattern, while all of the cells expressing the YXXФ mutant showed the second pattern of localization (Figure 3B). The wild type $3 \mathrm{a}$ and $\triangle \mathrm{EXD}$ proteins appear to be rapidly sorted from the Golgi complex to the plasma membrane. These results suggest that the di-acidic motif does not function as an ER export signal in this protein; if this was the case, the $\triangle \mathrm{EXD}$ mutant protein would have been retained in the ER. None of the proteins showed any significant localization with 
A

COS

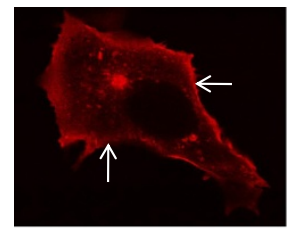

B
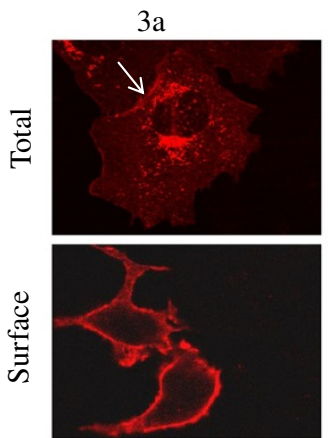

HT29

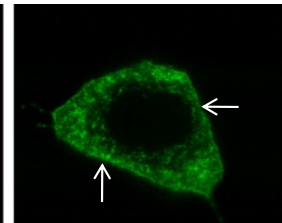

Cyto3a
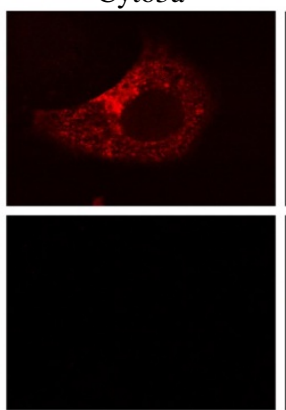

MDCK

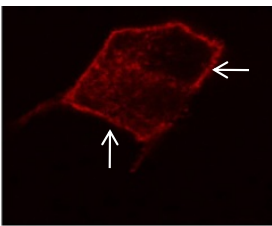

$\triangle \mathrm{YXX} \Phi$

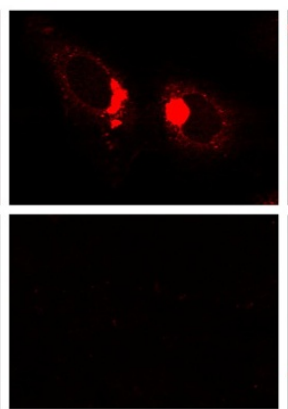

Huh7

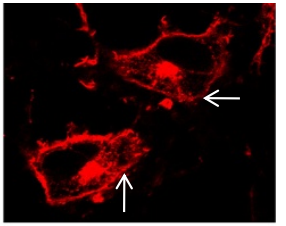

$\Delta \mathrm{EXD}$

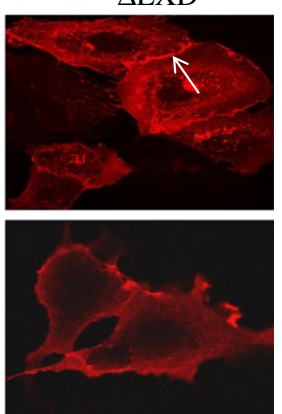

Figure 2 Mutation of the tyrosine based sorting motif abrogates surface expression of the 3a protein. (A) Distribution of $3 a$ protein in different cell lines - COS-7, HT29, MDCK and Huh7. The pSGI-3A-HA construct was transfected into these cell lines and stained with rabbit anti-3a antibody and Alexa-594 conjugated anti-rabbit lgG. (B) Surface expression of 3a and its mutants - Huh7 cells were transfected with expression constructs for wild type or mutant 3a proteins. Protein expression on the cell surface was detected using an anti-Myc antibody without permeabilizing the cells; the total levels were detected with anti-3a antibody after permeabilizing the cells with methanol. Arrow indicates surface distribution. Data shown are representative of three different experiments.

the ER marker. The $\triangle Y X X \Phi$ mutant protein was retained in the Golgi complex but not in the ER region or at the plasma membrane, suggesting that the tyrosine-based sorting motif is crucial for the sorting of the $3 a$ protein from Golgi to the plasma membrane.

\section{Increased Golgi retention of the 3a protein leads to increased targeting to lipid droplets}

Cytoplasmic lipid droplets have been proposed to act as storage vesicles for proteins [40]. Increased Golgi retention of Caveolin-2 is reported to result in targeting of the protein to lipid droplets [41]. We investigated whether this was also the case with Golgi-saturated 3a proteins. To visualize lipid droplets we used the specific dye Nile Red to stain transfected cells grown in culture media containing free fatty acids. On costaining with Nile Red, 50\% of the wild type 3 a protein was found to be associated with lipid droplets, but the Cyto3a protein did not show any significant colocalization, indicating that the transmembrane region of the 3a protein was required for its targeting to lipid droplets (Figure 4). Presuming that these act as storage vesicles for excess or unfolded proteins, Golgi overload would cause increased targeting to lipid droplets. Expectedly, over $90 \%$ of the $\triangle \mathrm{YXX} \Phi$ mutant 3a protein localized to lipid droplets (Figure 4).
Reduced levels of the $\triangle Y X X \Phi$ 3a protein are due to increased lysosomal degradation

In multiple transient transfections, we observed that the $\triangle Y X X \Phi$ mutant protein was expressed at much lower levels as compared to the wild type 3 a protein (Figure 5 A left panel). To investigate this, semi-quantitative RTPCR was performed, which showed the mRNA levels of the wild type and mutant 3 a proteins to be similar (Figure 5A right panel). This indicated that the mutant protein was either unstable or was actively degraded in the transfected cells. To explore this, we performed an in vitro transcription-translation experiment and found similar levels of the wild type and $\triangle \mathrm{YXX} \Phi$ mutant $3 \mathrm{a}$ proteins (Figure 5B), which supported the intracellular degradation model. Since the mutant protein was retained in lipid droplets, we hypothesized that this would lead to increased autophagy or lysosomal degradation. In fact, the $\triangle Y X X \Phi$ mutant protein localized with late endosome/ lysosomal marker Rab7 (Figure 5C). To further confirm lysosomal degradation of the mutant protein, we used two inhibitors - Brefeldin A, which blocks ER-to-Golgi transport and Aprotinin A, which inhibits lysosomal proteases. Both of these led to 3 to 5 fold increased levels of the $\triangle Y X X \Phi$ mutant protein (Figure 5D). These findings clearly demonstrate that mutation of the tyrosine-based 


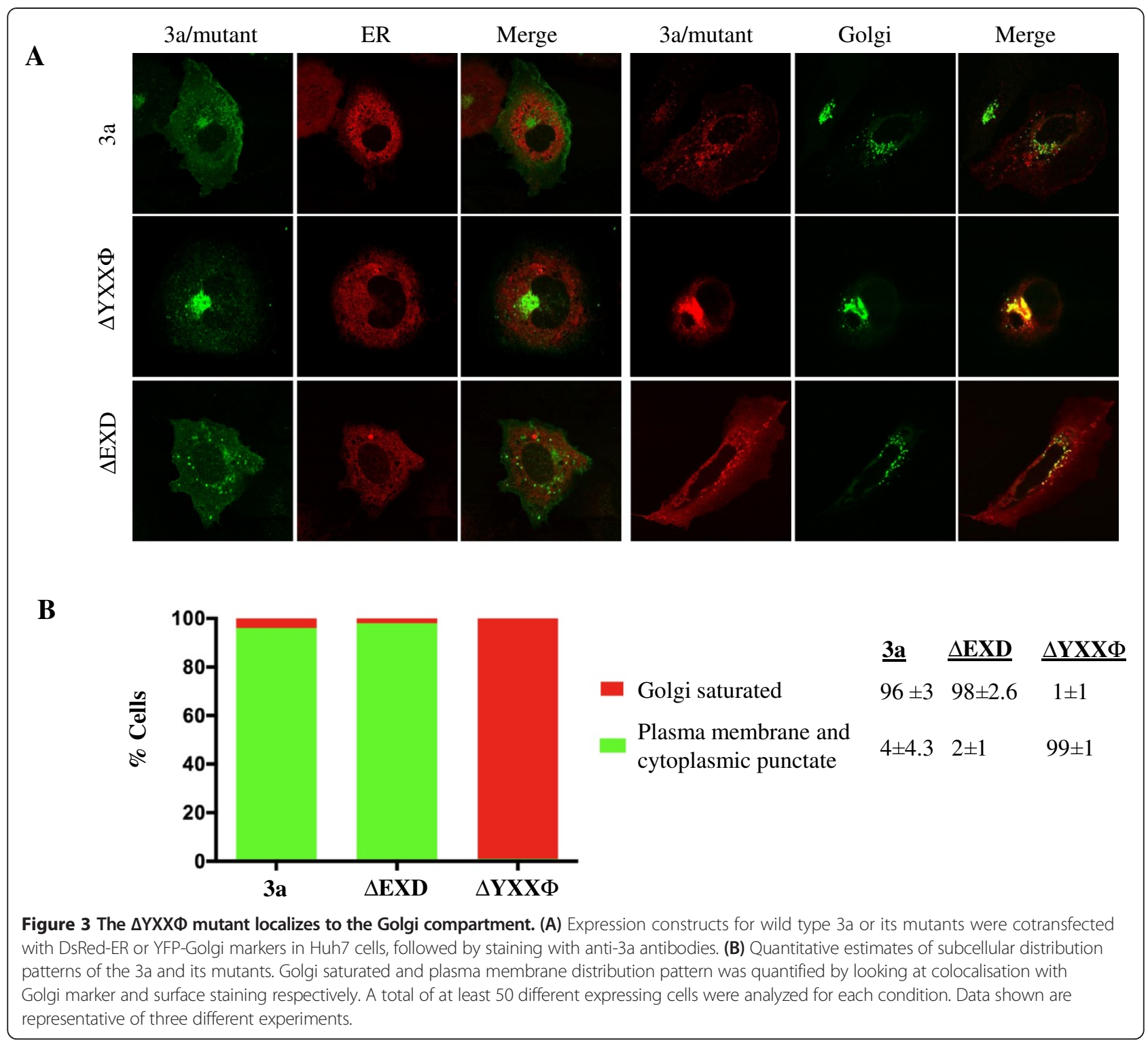

sorting motif causes abnormal trafficking of the 3a protein leading to increased accumulation in the Golgi compartment and lipid droplets and subsequent degradation in the lysosomal compartment.

\section{Discussion}

The 3 a protein is unique to SARS-CoV, not found in other human coronaviruses, and is important for disease pathogenesis. It functions as an ion channel [15], which is crucial for its pro-apoptotic role [42], and for this the 3a protein must traffic to the cell surface. This has been shown earlier [11] as well as in this report. However, the motifs or domains of the 3 a protein required for its cell surface distribution have not been characterized.

In many proteins, a tyrosine based sorting motif is responsible for internalization of molecules from the plasma membrane to intracellular sites by specific recognition of the cargo containing this motif through the plasma membrane resident Clathrin AP-2 complex [21]. Consequently, it was proposed that the YXXФ motif within the 3a protein would be important for its endocytosis [19]. If the YXXФ motif were important for mediating endocytosis from plasma membrane, the mutant 3a protein lacking this motif would be retained in the plasma membrane. However, this mutant protein was not found in the plasma membrane, but in the Golgi compartment, suggesting a role for this motif in Golgi to plasma membrane transport. The YXXФ motif is also recognized by the $\mathrm{AP}-1, \mathrm{AP}-3$ and $\mathrm{AP}-4$ complexes, of which the AP-4 complex is responsible for Golgi to plasma membrane transport [22]. However, in a preliminary experiment we did not observe any interaction of 


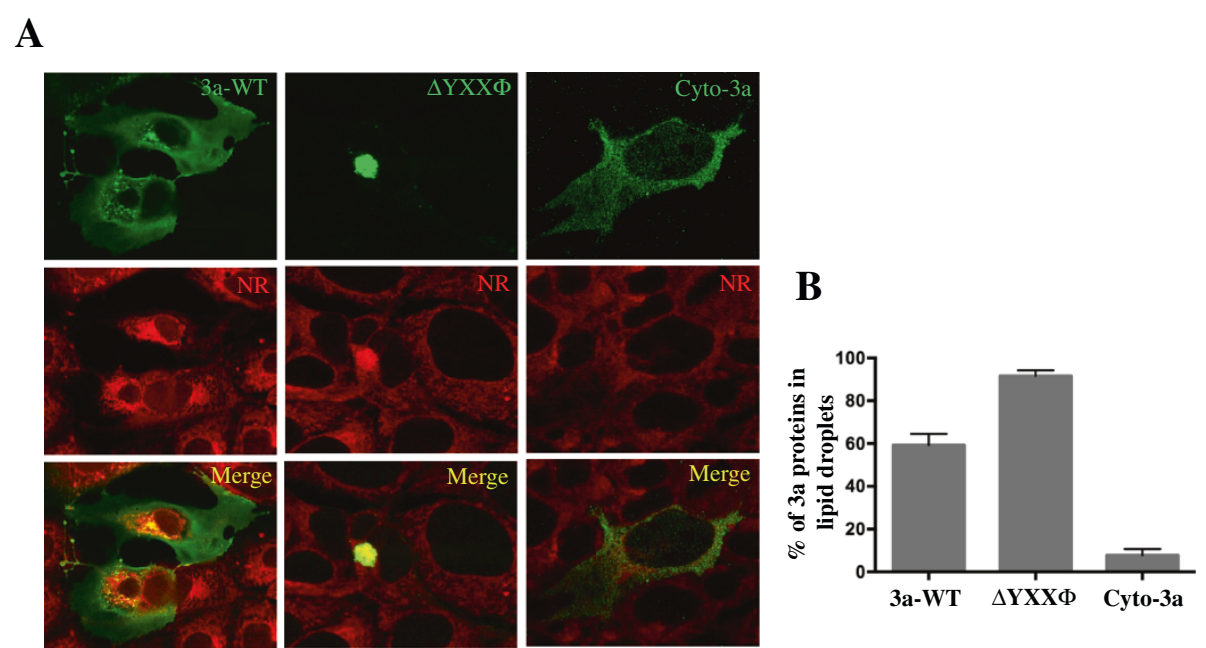

Figure 4 The $\triangle Y X X \Phi$ mutant is targeted to lipid droplets. (A) Huh7 cells were transfected with the indicated expression constructs. After $48 \mathrm{hr}$ cells were treated with $1 \mathrm{mM}$ fatty acids for $6 \mathrm{hr}$ and then lipid droplets were stained with Nile Red. The 3a was stained with anti-3a antibodies. (B) Percent of the indicated 3a proteins in lipid droplets were quantified by determining colocalization coefficient in at least 50 different expressing cells as described. Data shown are representative of three different experiments.

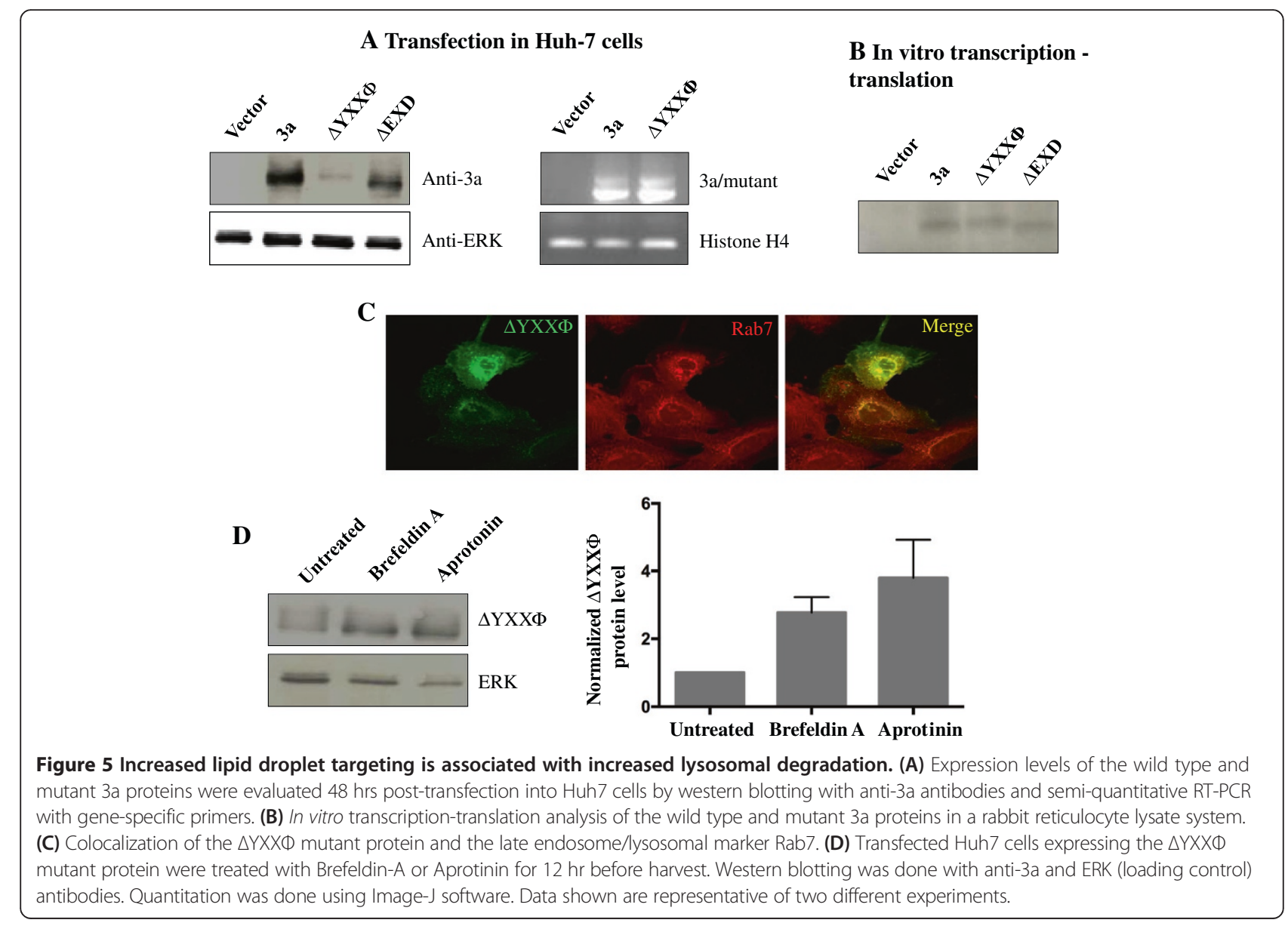


the 3a protein with AP-4 in a yeast two-hybrid assay (unpublished data). This, as well as alternate mechanisms need further investigation. The di-acidic motif functions as a canonical ER export signal in many proteins [24-28]. A mutant 3a protein lacking this motif was efficiently transported from the ER to Golgi and the plasma membrane. Thus, the EXD motif does not functions as an ER export signal in the 3a protein.

We also found the 3 a protein of SARS-CoV to be localized to lipid droplets. The transmembrane domains of the $3 \mathrm{a}$ protein are responsible for targeting it to lipid droplets since the Cyto3a protein that lacks the transmembrane domains did not localize to lipid droplets. It was shown earlier that hydrophobic domains of Perilipin $A$ and the core proteins of HCV and GBV-B are crucial for lipid droplets targeting [35,39]. Lipid droplets are shown to act as storage vesicles for excess and unfolded proteins $[34,40]$. It has been reported that Golgi mislocalization of Caveolin-1 leads to its targeting into lipid bodies [43]. Over-expressed Caveolin-2 is also partially targeted to lipid droplets [38]. In addition Caveolin-1 accumulates in lipid droplets when it is linked to an ERretrieval sequence (Cav-KKSL) [44]. A mutant Caveolin protein $\left(\mathrm{Cav} 3^{\mathrm{DGV}}\right)$ that mislocalizes in the Golgi, accumulates irreversibly in lipid droplets [41]. We observed that the 3a $\triangle Y X X \Phi$ mutant that is retained in the Golgi is also associated with lipid droplets.

Targeting to lipid droplets could be a pathway for protein degradation. In fact, inhibitors of autophagy and proteosomal degradation led to increased protein levels and lipid droplet association of Apolipoprotein B [37]. We observed that reduced protein levels of $\triangle Y X X \Phi$ mutant were associated with increased lysosomal degradation. There was a 3 to 5 fold increase in $\triangle \mathrm{YXX \Phi} \mathrm{protein} \mathrm{levels}$ on treatment with Brefeldin A or Aprotinin. Based on these data, we put forward a new model of intracellular distribution of the 3a protein (Figure 6). We propose that the wild type 3a protein is sorted efficiently from the ER and Golgi to the plasma membrane. The $\triangle \mathrm{YXX} \Phi$ mutant fails to reach the plasma membrane as it gets stuck in the Golgi compartment. This mutant protein is then targeted to lipid droplets and ultimately to the protein degradation machinery.

In conclusion, surface expression of the 3a protein is mediated by the crucial YXX $\Phi$ motif, in the absence of which the 3 a protein is retained in the Golgi compartment destined for lysosomal degradation via lipid droplets. This finding demonstrates a novel role of the YXXФ motif in intracellular protein transport.

\section{Materials and methods Materials}

All common reagents were purchased from Sigma Chemical Co. (St. Louis, MO, USA) unless stated otherwise.
COS-1 and Huh7 cells were obtained from American Type Culture Collection (Manassas, Va, USA), while MDCK and HT29 cells were obtained from the National Animal Cell Repository, National Centre for Cell Sciences (Pune, India). All cell lines were cultured at $37^{\circ} \mathrm{C}$ in $10 \%$ $\mathrm{CO}_{2}$ in complete Dulbecco modified Eagle medium (DMEM containing $1 \mathrm{~g}$ /lit glucose, $2 \mathrm{mM}$ L-glutamine, $1.5 \mathrm{~g} /$ lit sodium bicarbonate, $0.1 \mathrm{mM}$ non-essential amino acids, $0.1 \mathrm{mg} / \mathrm{ml}$ streptomycin, $100 \mathrm{U}$ penicillin) and $5 \%$ fetal bovine serum (FBS). Anti-3a antibodies were generated using the purified cytoplasmic domain of the 3a protein as described earlier [29].

\section{Plasmid constructs}

The orf3a (nucleotides 25,268 to 26,092) of the SARSCoV genome (GenBank accession number NC_004718, Tor2 isolate) and its cytoplasmic domain were cloned into the eukaryotic plasmid vector pSGI-HA to give expression vectors pSGI-3A-HA and pSGI-3ACyto-HA, as described earlier [29]. N-terminal Myc-tag was added to the $3 \mathrm{~A}$ and its different mutants by taking c-Mycepitope tag from pGBKT7 vectors.

\section{Site directed mutagenesis}

The $\triangle \mathrm{YXX} \Phi$ mutant of 3a was created by mutating the tyrosine and valine residues in the YXXV motif (aa 160163) to alanine and glycine respectively, using primers YF1: TGTATACCAGCTAACAGCCTCACAG and YR1: CTGTGGCACTGTTAGCTGGTATACA. The $\triangle$ EXD mutant was created by mutating glutamic acid and aspartic acid residues in the EXD motif (aa 171-173) into alanines, using primers EF1: GTCGTTACTGCAGGTGCCGGCAT TTC and ER1: GAAATGCCG GCACCTGCAGTAACG AC. Site directed mutagenesis was carried out using the QuickChange site directed mutagenesis kit system (Stratagene) according to the manufacturer's protocol. All mutations were verified by DNA sequencing.

\section{Tranfection and western blotting}

Cells were transfected using Lipofectin as described earlier [14] and were harvested in PBS $48 \mathrm{hr}$ post-transfection. For experiments with inhibitors, transfected cells were treated with Brefeldin A or Aprotinin as per the manufacturer's instruction (Sigma) for $12 \mathrm{hr}$ before harvest. Western blotting was done after lysing the cells with lysis buffer $(10 \mathrm{mM}$ Tris $\mathrm{pH} 7.6,150 \mathrm{mM} \mathrm{NaCl}, 1 \%$ Triton-X100) with protease inhibitors as described earlier [14].

\section{Semi-quantitative RT-PCR}

RNA was isolated from transfected cells $48 \mathrm{hr}$ posttransfection using Trizol reagent (Invitrogen). Equal amounts of RNA were taken for reverse transcription using Superscript reverse transcriptase (Life Technologies). Semi-quantitative PCR was done using gene specific 


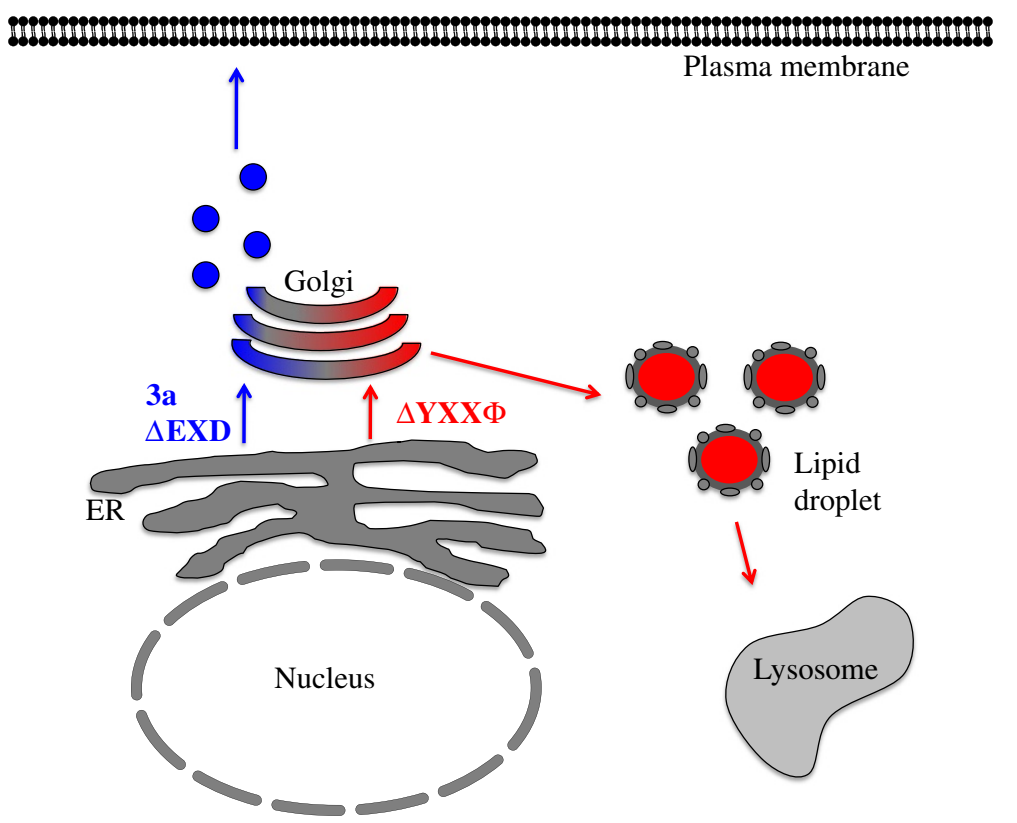

Figure 6 A model of intracellular trafficking of the 3a protein. The wild type 3a protein or the $\triangle E X D$ mutant are sorted from Golgi to plasma membrane whereas the $\triangle Y X X \Phi$ mutant protein is retained in the Golgi and is targeted to lysosomal compartment for degradation via lipid droplets.

primers 3aF1, GAATTCATGGATTTGT TTATGAGATTT, and 3aR1, AGATCTCAAAGGCACGCTAGTAGT. The PCR reaction was carried out for only 20 cycles, which was found previously to be in the linear phase before reaching saturation.

Immunofluorescence staining and subcellular localization For transient transfection, cells were grown on coverslips to $40-50 \%$ confluence and transfected with Lipofectin reagent (Invitrogen, USA) in antibiotic-free and serum-free DMEM. Six hours post-transfection, the medium was removed and replaced with complete DMEM containing 5\% FBS. Around $48 \mathrm{hr}$ post-transfection, cells were washed with PBS and fixed with $2 \%$ paraformaldehyde for $15 \mathrm{~min}$ at room temperature. For antibody staining, cells were permeabilized with $100 \%$ methanol for $3 \mathrm{~min}$ at $-20^{\circ} \mathrm{C}$, blocked with PBS containing 5\% goat serum for $45 \mathrm{~min}$ and then incubated with a 1:200 dilution of the primary antibodies in PBS for $1 \mathrm{hr}$ at room temperature. The cells were washed thrice for 5 min each with PBS and then incubated with a 1:200 dilution of the relevant secondary antibodies conjugated with either Alexa 488 or Alexa 594 (Molecular Probes, USA) in PBS for $1 \mathrm{hr}$. The coverslips were mounted on slides with Antifade reagent (Bio-Rad, USA) and sealed with a synthetic rubber-based adhesive (Fevicol; Pidilite Industries, India). Confocal images were collected using a 60x objective in a Bio-Rad Radiance 2001 laser-scanning confocal system attached to a Nikon Eclipse TE-2000U inverted microscope. For subcellular localization, cells were cotransfected to express the required protein and a relevant fluorescent subcellular marker. For the studies reported here, the markers included DsRed-ER and YFP-Golgi that are part of the Living Colors ${ }^{\mathrm{TM}}$ Subcellular Localization Vector set (Clontech). To determine percent colocalization of different proteins; images were analyzed by Nikon Elements Software and the Pearson coefficient for colocalization was calculated.

\section{Nile red staining}

Transfected Huh7 cells were transferred 48 hrs posttransfection to Glucose-free media (Sigma) containing $1 \mathrm{mM}$ fatty acids $(0.5 \mathrm{mM}$ Oleic acid and $0.5 \mathrm{mM}$ Palmitoleic acid). After $6 \mathrm{hr}$, the media was removed followed by a brief wash with PBS. Cells were stained with $10 \mu \mathrm{M}$ Nile Red (Sigma) in PBS for 20 min at room temperature. The stain was removed and cells were washed twice with PBS. In case of co-staining with anti-3a antibodies, cells were first stained for $3 \mathrm{a}$ followed by Nile Red staining.

\section{In vitro transcription and translation}

The gene to be expressed was cloned downstream of a T7 promoter in the pSGI expression vector [29]. The plasmid was then added to the reaction mixture containing T7 polymerase, amino-acid mixture (lacking methionine), appropriate buffer and rabbit reticulocyte lysate using the $\mathrm{TNT}^{\otimes}$ quick coupled transcription/translation system kit (Promega Corporation, USA) according to the 
manufacturer's guidelines. Exogenously added $\left[{ }^{35} \mathrm{~S}\right]$ methionine/cysteine was used $(>1,000 \mathrm{Ci} / \mathrm{ml})$ to label the protein as recommended for $90 \mathrm{~min}$ at $30^{\circ} \mathrm{C}$. Subsequently, the in vitro synthesized proteins were analyzed by SDS-PAGE and fluorography.

\section{Competing interests}

The authors have no competing interests.

\section{Authors' contribution}

K.P. conceived and designed the experiments; R.M. and K.P. performed the experiments and wrote the manuscript. Both authors read and approved the final manuscript.

\section{Acknowledgement}

We thank Dr. Shahid Jameel for generously providing us lab space and reagents to conduct the experiments. We also thank Dr. Manjula Kalia and Charu Tanwar for their help with confocal microscopy. A Senior Research Fellowship to K.P. from CSIR (India) is gratefully acknowledged.

\section{Disclaimer}

This work was done while KP was with ICGEB, New Delhi, India.

\section{Funding}

This work was supported by a grant from the Department of Biotechnology (DBT), Government of India. The funding agency had no role in designing and execution of the experiments, data analysis and preparation of the manuscript.

Received: 17 January 2014 Accepted: 4 April 2014

Published: 24 April 2014

\section{References}

1. Drosten C, Gunther S, Preiser W, van der Werf S, Brodt HR, Becker S, Rabenau H, Panning M, Kolesnikova L, Fouchier RA, Berger A, Burguiere AM, Cinatl J, Eickmann M, Escriou N, Grywna K, Kramme S, Manuguerra JC, Muller S, Rickerts V, Sturmer M, Vieth S, Klenk HD, Osterhaus AD, Schmitz H, Doerr HW: Identification of a novel coronavirus in patients with severe acute respiratory syndrome. N Engl J Med 2003, 348:1967-1976.

2. Lee $N$, Hui D, Wu A, Chan P, Cameron P, Joynt GM, Ahuja A, Yung MY, Leung CB, To KF, Lui SF, Szeto CC, Chung S, Sung JJ, Joynt GM, Ahuja A, Yung MY, Leung CB, To KF, Lui SF, Szeto CC, Chung S, Sung JJ: A major outbreak of severe acute respiratory syndrome in Hong Kong. N Engl J Med 2003, 348:1986-1994.

3. Poutanen SM, Low DE, Henry B, Finkelstein S, Rose D, Green K, Tellier R, Draker R, Adachi D, Ayers M, Chan AK, Skowronski DM, Salit I, Simor AE, Slutsky AS, Doyle PW, Krajden M, Petric M, Brunham RC, McGeer AJ: Identification of severe acute respiratory syndrome in Canada. N Engl J Med 2003, 348:1995-2005.

4. Tsang KW, Ho PL, Ooi GC, Yee WK, Wang T, Chan-Yeung M, Lam WK, Seto WH, Yam LY, Cheung TM, Wong PC, Lam B, Ip MS, Chan J, Yuen KY, Lai KN: A cluster of cases of severe acute respiratory syndrome in Hong Kong. N Engl J Med 2003, 348:1977-1985.

5. Marra MA, Jones SJ, Astell CR, Holt RA, Brooks-Wilson A, Butterfield YS, Khattra J, Asano JK, Barber SA, Chan SY, Cloutier A, Coughlin SM, Freeman D, Girn N, Griffith OL, Leach SR, Mayo M, McDonald H, Montgomery SB, Pandoh PK, Petrescu AS, Robertson AG, Schein JE, Siddiqui A, Smailus DE, Stott JM, Yang GS, Plummer F, Andonov A, Artsob H, et al: The Genome sequence of the SARS-associated coronavirus. Science 2003, 300:1399-1404.

6. Rota PA, Oberste MS, Monroe SS, Nix WA, Campagnoli R, Icenogle JP, Penaranda S, Bankamp B, Maher K, Chen MH, Tong S, Tamin A, Lowe L, Frace M, DeRisi JL, Chen Q, Wang D, Erdman DD, Peret TC, Burns C, Ksiazek TG, Rollin PE, Sanchez A, Liffick S, Holloway B, Limor J, McCaustland K, Olsen-Rasmussen M, Fouchier R, Gunther S, et al: Characterization of a novel coronavirus associated with severe acute respiratory syndrome. Science 2003, 300:1394-1399.

7. Yount B, Roberts RS, Sims AC, Deming D, Frieman MB, Sparks J, Denison MR, Davis N, Baric RS: Severe acute respiratory syndrome coronavirus group-specific open reading frames encode nonessential functions for replication in cell cultures and mice. J Virol 2005, 79:14909-14922.

8. Tan YJ, Goh PY, Fielding BC, Shen S, Chou CF, Fu JL, Leong HN, Leo YS, Ooi $E E$, Ling $A E$, Lim SG, Hong W: Profiles of antibody responses against severe acute respiratory syndrome coronavirus recombinant proteins and their potential use as diagnostic markers. Clin Diagn Lab Immunol 2004, 11:362-371.

9. Ito N, Mossel EC, Narayanan K, Popov VL, Huang C, Inoue T, Peters CJ, Makino S: Severe acute respiratory syndrome coronavirus $3 a$ protein is a viral structural protein. J Virol 2005, 79:3182-3186.

10. Shen S, Lin PS, Chao YC, Zhang A, Yang X, Lim SG, Hong W, Tan YJ: The severe acute respiratory syndrome coronavirus $3 a$ is a novel structural protein. Biochem Biophys Res Commun 2005, 330:286-292.

11. Tan YJ, Teng E, Shen S, Tan TH, Goh PY, Fielding BC, Ooi EE, Tan HC, Lim SG, Hong W: A novel severe acute respiratory syndrome coronavirus protein, U274, is transported to the cell surface and undergoes endocytosis. J Virol 2004, 78:6723-6734

12. Freundt EC, Yu L, Goldsmith CS, Welsh S, Cheng A, Yount B, Liu W, Frieman MB, Buchholz UJ, Screaton GR, Lippincott-Schwartz J, Zaki SR, Xu XN, Baric $\mathrm{RS}$, Subbarao K, Lenardo MJ: The open reading frame 3a protein of severe acute respiratory syndrome-associated coronavirus promotes membrane rearrangement and cell death. J Virol 2010, 84:1097-1109.

13. Law PT, Wong CH, Au TC, Chuck CP, Kong SK, Chan PK, To KF, Lo AW, Chan JY, Suen YK, Chan HY, Fung KP, Waye MM, Sung JJ, Lo YM, Tsui SK: The 3a protein of severe acute respiratory syndrome-associated coronavirus induces apoptosis in Vero E6 cells. J General Virol 2005 86:1921-1930.

14. Padhan K, Minakshi R, Towheed MA, Jameel S: Severe acute respiratory syndrome coronavirus 3 a protein activates the mitochondrial death pathway through p38 MAP kinase activation. J Gen Virol 2008, 89:1960-1969

15. Lu W, Zheng BJ, Xu K, Schwarz W, Du L, Wong CK, Chen J, Duan S, Deubel $\checkmark$, Sun B: Severe acute respiratory syndrome-associated coronavirus $3 a$ protein forms an ion channel and modulates virus release. Proc Natl Acad Sci U S A 2006, 103:12540-12545.

16. Obitsu S, Ahmed N, Nishitsuji H, Hasegawa A, Nakahama K, Morita I, Nishigaki K, Hayashi T, Masuda T, Kannagi M: Potential enhancement of osteoclastogenesis by severe acute respiratory syndrome coronavirus 3a/X1 protein. Arch Virol 2009, 154:1457-1464

17. Minakshi R, Padhan K, Rani M, Khan N, Ahmad F, Jameel S: The SARS Coronavirus 3 a protein causes endoplasmic reticulum stress and induces ligand-independent downregulation of the type 1 interferon receptor. PLoS One 2009, 4:e8342.

18. Zeng $R$, Yang RF, Shi MD, Jiang MR, Xie $Y H$, Ruan $H Q$, Jiang $X S$, Shi L, Zhou $H$, Zhang $L$, Wu XD, Lin $Y$, Ji $Y Y$, Xiong $L$, Jin $Y$, Dai EH, Wang $X Y$, Si BY, Wang J, Wang HX, Wang CE, Gan YH, Li YC, Cao JT, Zuo JP, Shan SF, Xie E, Chen SH, Jiang ZQ, Zhang X: Characterization of the 3a protein of SARSassociated coronavirus in infected vero E6 cells and SARS patients. J Mol Biol 2004, 341:271-279.

19. Tan YJ: The Severe Acute Respiratory Syndrome (SARS)-coronavirus 3a protein may function as a modulator of the trafficking properties of the spike protein. Virol J 2005, 2:5.

20. Huang C, Narayanan K, Ito N, Peters CJ, Makino S: Severe acute respiratory syndrome coronavirus 3 a protein is released in membranous structures from $3 a$ protein-expressing cells and infected cells. $J$ Virol 2006, 80:210-217.

21. Bonifacino JS, Dell'Angelica EC: Molecular bases for the recognition of tyrosine-based sorting signals. J Cell Biol 1999, 145:923-926.

22. Bonifacino JS, Traub LM: Signals for sorting of transmembrane proteins to endosomes and lysosomes. Annu Rev Biochem 2003, 72:395-447.

23. Letourneur F, Klausner RD: A novel di-leucine motif and a tyrosine-based motif independently mediate lysosomal targeting and endocytosis of CD3 chains. Cell 1992, 69:1143-1157.

24. Hanton SL, Renna L, Bortolotti LE, Chatre L, Stefano G, Brandizzi F: Diacidic motifs influence the export of transmembrane proteins from the endoplasmic reticulum in plant cells. Plant Cell 2005, 17:3081-3093.

25. Phillipson BA, Pimpl P, daSilva LL, Crofts AJ, Taylor JP, Movafeghi A, Robinson DG, Denecke J: Secretory bulk flow of soluble proteins is efficient and COPII dependent. Plant Cell 2001, 13:2005-2020.

26. Nishimura N, Balch WE: A di-acidic signal required for selective export from the endoplasmic reticulum. Science 1997, 277:556-558. 
27. Votsmeier C, Gallwitz D: An acidic sequence of a putative yeast Golgi membrane protein binds COPII and facilitates ER export. EMBO J 2001, 20:6742-6750.

28. Mikosch M, Hurst AC, Hertel B, Homann U: Diacidic motif is required for efficient transport of the $\mathrm{K}+$ channel KAT1 to the plasma membrane. Plant Physiol 2006, 142:923-930.

29. Padhan K, Tanwar C, Hussain A, Hui PY, Lee MY, Cheung CY, Peiris JS, Jameel S: Severe acute respiratory syndrome coronavirus Orf3a protein interacts with caveolin. J Gen Virol 2007, 88:3067-3077.

30. Murata M, Peranen J, Schreiner R, Wieland F, Kurzchalia TV, Simons K: VIP21/ caveolin is a cholesterol-binding protein. Proc Natl Acad Sci U S A 1995, 92:10339-10343.

31. Cohen AW, Razani B, Schubert W, Williams TM, Wang XB, lyengar P, Brasaemle DL, Scherer PE, Lisanti MP: Role of caveolin-1 in the modulation of lipolysis and lipid droplet formation. Diabetes 2004, 53:1261-1270.

32. Rothberg KG, Heuser JE, Donzell WC, Ying YS, Glenney JR, Anderson RG: Caveolin, a protein component of caveolae membrane coats. Cell 1992, 68:673-682.

33. Martin S, Parton RG: Lipid droplets: a unified view of a dynamic organelle. Nat Rev Mol Cell Biol 2006, 7:373-378.

34. Cermelli S, Guo Y, Gross SP, Welte MA: The lipid-droplet proteome reveals that droplets are a protein-storage depot. Current biol CB 2006, 16:1783-1795.

35. Subramanian V, Garcia A, Sekowski A, Brasaemle DL: Hydrophobic sequences target and anchor perilipin A to lipid droplets. J Lipid Res 2004, 45:1983-1991.

36. Jiang H, He J, Pu S, Tang C, Xu G: Heat shock protein 70 is translocated to lipid droplets in rat adipocytes upon heat stimulation. Biochim Biophys Acta 2007, 1771:66-74.

37. Ohsaki Y, Cheng J, Fujita A, Tokumoto T, Fujimoto T: Cytoplasmic lipid droplets are sites of convergence of proteasomal and autophagic degradation of apolipoprotein B. Mol Biol Cell 2006, 17:2674-2683.

38. Fujimoto T, Kogo H, Ishiguro K, Tauchi K, Nomura R: Caveolin-2 is targeted to lipid droplets, a new "membrane domain" in the cell. J Cell Biol 2001, 152:1079-1085.

39. Hope RG, Murphy DJ, McLauchlan J: The domains required to direct core proteins of hepatitis $C$ virus and $G B$ virus-B to lipid droplets share common features with plant oleosin proteins. J Biol chem 2002, 277:4261-4270.

40. Welte MA: Proteins under new management: lipid droplets deliver. Trends Cell Biol 2007, 17:363-369.

41. Pol A, Luetterforst R, Lindsay M, Heino S, Ikonen E, Parton RG: A caveolin dominant negative mutant associates with lipid bodies and induces intracellular cholesterol imbalance. J Cell Biol 2001, 152:1057-1070.

42. Chan CM, Tsoi H, Chan WM, Zhai S, Wong CO, Yao X, Chan WY, Tsui SK, Chan HY: The ion channel activity of the SARS-coronavirus 3a protein is linked to its pro-apoptotic function. Int J Biochem Cell Biol 2009, 41:2232-2239.

43. Wyse BD, Prior IA, Qian H, Morrow IC, Nixon S, Muncke C, Kurzchalia TV, Thomas WG, Parton RG, Hancock JF: Caveolin interacts with the angiotensin II type 1 receptor during exocytic transport but not at the plasma membrane. J Biol Chem 2003, 278:23738-23746.

44. Ostermeyer AG, Paci JM, Zeng Y, Lublin DM, Munro S, Brown DA: Accumulation of caveolin in the endoplasmic reticulum redirects the protein to lipid storage droplets. J Cell Biol 2001, 152:1071-1078.

\section{Submit your next manuscript to BioMed Central and take full advantage of:}

- Convenient online submission

- Thorough peer review

- No space constraints or color figure charges

- Immediate publication on acceptance

- Inclusion in PubMed, CAS, Scopus and Google Scholar

- Research which is freely available for redistribution

Submit your manuscript at www.biomedcentral.com/submit 